\title{
ポテンシャル勾配を用いたナノチャネル内の流体分子駆動
}

\author{
学 石山達也 $\bigcirc($ 北大・院 $)$ 正 望月 修 (北大・工) 正 石川仁 (北大・工)
}

\section{Fluid Molecular Drive in a Nano-Channel \\ Due to Intermolecular Potential Gradient}

Tatsuya Ishiyama and Osamu Mochizuki and Hitoshi Ishikawa

\begin{abstract}
Molecular flow induced by intermolecular potential gradient between solid and fluid was analyzed by a MD method. Platinum (Pt) and xenon (Xe) were used as solid and fluid respectively. The number of Xe molecules was 100 and that of Pt atoms composing walls of nano-channel was 2400 . The wall temperature was fixed at $300 \mathrm{~K}$. It was found that a longitudinal rotating flow in the nano-channel could be driven by the potential gradient.
\end{abstract}

Key Words; Molecular Dynamics, Potential Gradient, Xenon, Platinum

\section{1 緒論}

近年,「ナノテクノロジー」がクローズアップされている. 現在の技術は，もはやマイクロテクノロジーをも越え，原子 分子オーダーにまで足を踏み入れようとしている．流体分子 駆動という観点から，固体壁に沿う方向に密度勾配 [1] や温 度勾配 [2] 設定して流れを駆動する研究などが行われてい る。これらは，いずれも外部からエネルギーを与え続ける事 で，流れを誘起させる事ができる、

本研究は, 原子, 分子の運動を支配するポテンシャルエネ ルギーに注目し，異種原子間ポテンシャルに勾配を持たせる 事によって，流れを駆動しようとするものである。つまり， 常時外部からエネルギーを与える事なく，電気的に中性であ る分子が衝突の瞬間に生じる誘導分極を利用して，固体原子 近傍で勾配力を働かせるのである，なお，本研究では，実在 する原子のポテンシャルパラメータを用いてはいるが，ポテ ンシャル勾配にのみ仮想的な值を用いている事に注意された い. 現実的には，ポテンシャル勾配を作るために，異種固体 原子結晶を作り出寸必要があるが，原子操作が可能である現 在の技術においてポテンシャル勾配を作り出すことは決して 不可能ではないと考えている。

\section{2 解析方法}

\section{1 原子, 分子間ポテンシャル}

固体原子, 流体分子共に以下に示す Lennard-Jones ポテ

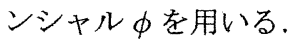

$$
\phi=4 \epsilon\left\{\left(\frac{\sigma}{r}\right)^{12}-\left(\frac{\sigma}{r}\right)^{6}\right\}
$$

ここで, $\epsilon$ はポテンシャルの谷の梁さ, $\sigma$ はみかけの原子半 径, $r$ は原子間距離を表す. 固体原子間ポテンシャルパラメー タには $\mathrm{Pt}$, 流体分子間ポテンシャルパラメータには単原子 分子である Xe を用いる [3]. これらの值を表 1 に示す。 ま た, 異種原子間ポテンシャルパラメータは, 勾配を与えない 壁面には,

$$
\sigma_{a b}=\frac{\sigma_{a}+\sigma_{b}}{2}, \quad \epsilon_{a b}=\frac{\epsilon_{a} \epsilon_{b}}{\epsilon_{a}+\epsilon_{b}}
$$

によって決定する [4]. また, 勾配を与える場合, 便宜上ポ テンシャルの谷の梁さ $\epsilon$ のみに勾配をつけ，その他のパラ メータは，表 1 に示す通りとする，なお， $k_{B}$ はボルツマン 定数である. 勾配の大きさについては, 次項で述べる.

\section{2 狺算モデル}

固体原子配置の配置図を，図 1 に示す，座標系はf.c.c 構 造をとる Pt 原子のミラー指数 (111) 断面が， $x y$ 面となる
Table 1: Lennard-Jones potential parameters

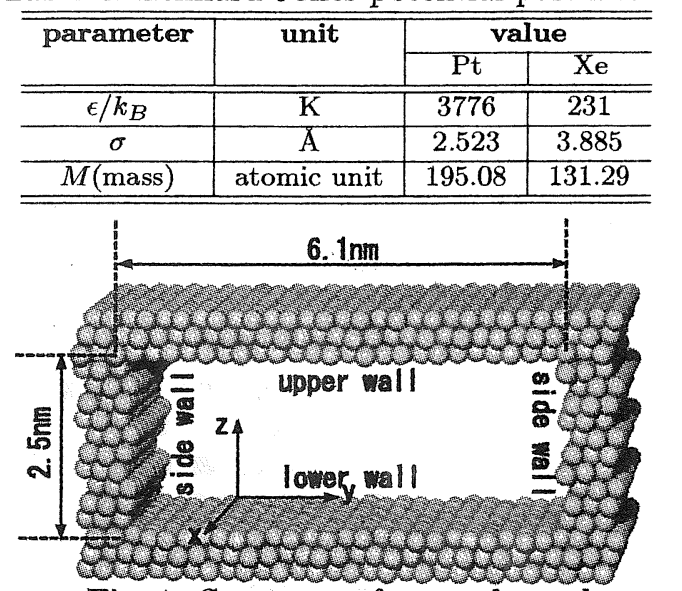

Fig. 1: Structure of nano-channel

ように決定した. これにより,ポテンシャル場が最も安定し た面を流路壁面とする事ができる，また，図 1 に示すように， 固体壁を 4 つのグループに分け， $10 \times 30 \times 3$ 個の原子から なる固体壁を upper wall, lower wall とし，その間に挟まれ る形で, $10 \times 3 \times 10$ 個の原子からなる固体壁を side wall と 定義寸る，固体壁温度は全て $300 \mathrm{~K}$ と一定にしている。

境界条件は， $x$ 方向に周期境界条件を課し， $y, z$ 方向に は，最も外側の固体原子の速度を 0 にすることで，その位置 を固定させる，これは，x軸方向に無限に長い nano-channel を想定している.

ポテンシャル勾配は, upper wall, lower wall のみに課 す. upper wall には負の $(d \phi / d y<0)$, lower wall には正 の $(d \phi / d y>0)$ ポテンシャル勾配を与え, ポテンシャルの 谷の樑さ $\epsilon$ を $y$ 方向一隣り合う原子に等差的に与える事に よって実現される．表 2 に示すように，勾配の大きさの順に case1 case3 を設定した。.また, case4 として，固体壁に勾 配を与えない場合についての計算も行った，Xe原子数は 100 であり，時間刻みは $6.3 \mathrm{fs}$ としている。

Table 2: Magnitude of potential parameter $\epsilon$

\begin{tabular}{c|c|c|c}
\hline \hline & $\begin{array}{c}\text { potential gradient } \\
\Delta \epsilon / \Delta y(\mathrm{~K})\end{array}$ & $\begin{array}{c}\text { minimum value } \\
\text { of } \epsilon / k_{B}(\mathrm{~K})\end{array}$ & $\begin{array}{c}\text { maximum value } \\
\text { of } \epsilon / k_{B}(\mathrm{~K})\end{array}$ \\
\hline \hline case1 & 9.0 & 30 & 300 \\
\hline case2 & 6.7 & 100 & 300 \\
\hline case3 & 0.3 & 290 & 300 \\
\hline case4 & 0.0 & 231 & 231 \\
\hline \hline
\end{tabular}




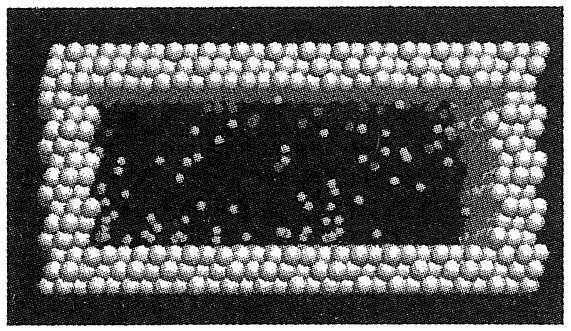

Fig. 2: Molecular distribution in the case1

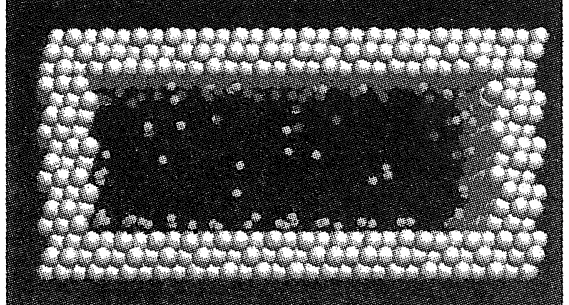

Fig. 3: Molecular distribution in the case3

\section{3 解析結果と考察}

\section{1 ポテンシャル場と吸着分子との関係}

ポテンシャル勾配を利用した流体の駆動を考えた場合，固 体表面近傍で形成される吸着層は，その機能の低下につなが る原因になると予想される、そこで, 分子運動をアニメーショ ンにより可視化することで，吸着分子とポテンシャル場との 関係を考える. 単純に考えれば，ポテンシャルエネルギーが $-300 \mathrm{~K}$ 以下の領域から， $300 \mathrm{~K}$ に相当する運動エネルギーを もった分子が離脱することは不可能である. そこで, case1 における $-300 \mathrm{~K}$ 以下の異種原子間ポテンシャル場を図 5 に, 分子運動のアニメーションをLink 1 として示す、また, Link 1 の画像の一部を図 2 に示しておく. 図 5 に示した吸着する と予想される領域で, 実際に分子の運動の拘束, 又は吸着が 起こり，数密度が大きくなっていることが確認できる，比較 として case3 における異種分子間ポテンシャル場を図 6 に, 分子運動のアニメーションを Link 2 に，その画像の一部を 図 3 に示しておく. case 3 では, ほとんど固体壁近傍が吸着 層で覆われていることが分かる。

\section{2 速度分布}

流速は，図 2 に示すようなチャネル内の流体分子が，想定 したセル内に飛び込んでくる分子の運動量を時間平均するこ とによって得られる．空間のセル分割数は， $\mathrm{x}$ 方向には周期 境界条件を課しているため，y,z 方向に $1 \times 10$ としている. ただし, y 方向のセルの大きさは, side wall の表面近傍を除 いた空間中央 $3 / 5$ の領域とした。これは, side wall の表面 がミラー指数 $(11 \overline{2})$ 断面であり，四凸の影響が大きく出てし まうためである、系が熱平衡状態に至ってからの総ステップ 数を $6 \times 10^{5}$ とし，100 ステップごとにサンプリングした. case1 case4 の速度分布を図 4 に示す．ここで， $\mathrm{z}$ 軸座標 の原点は， lower wall の表面としている. case1,case2 におい て，lower wall の表面近傍ではy の負の方向に, upper wall の表面近傍では正の方向に流速を得ていることがわかる.こ れは，個々の流体分子がポテンシャルエネルギーが小さくな る方向に運動量を得ていることを表している.これにより， 空間内で流体が回転していることが分かる．また，case1 で は, upper wall, lower wall にせん断速度を与えた時の速度 分布形状に似ている [3]. すなわち，ポテンシャル勾配を与え ることによって，あたかも固体壁面を駆動しているときと， 類似の速度分布を得ることができることを示している．一方， case 3,4 の速度分布は，全体的にほぼ 0 近傍に一様分布を示 寸。今回の計算では，流体分子数の少なさによる統計誤差が 原因で，そのゆらぎが大きく，速度分布の特徴を細かく読み 取れないが，さらに精度をあげる事が今後の課題である.

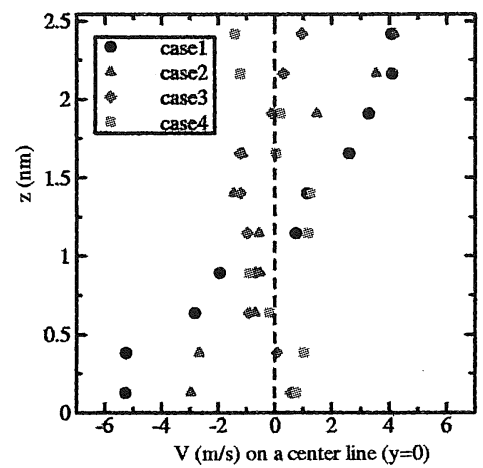

Fig. 4: Velocity profile (case1 case4)

\section{4 結論}

壁面に沿って与えられたポテンシャル勾配による流れの駆 動を行った. ポテンシャルエネルギーの大きい場所から小さ い場所に向かって流れを駆動させることが確認できた。これ により，外部から常時エネルギーを与えることなく流体を駆 動させる可能性を示唆することができた。なお，今後の課題 として，ポテンシャル勾配による駆動性能と，吸着分子との 関係を明らかにする予定である。

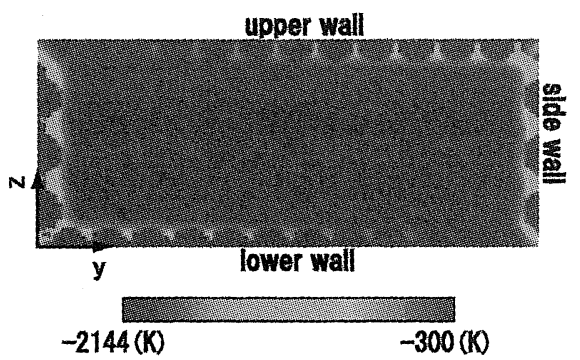

Fig. 5: Potential field in the case1

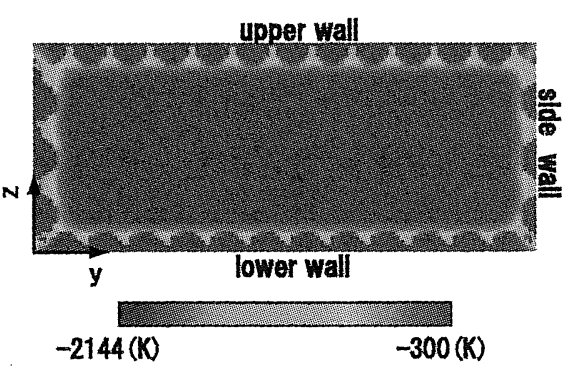

Fig. 6: Potential field in the case3

\section{参考文献}

[1] 齋藤賢一, 行天義幸, 稲葉武彦. ナノ空間に制約された窒素分子 流動の非平衡分子動力学. 日本機械学会流体工学部門講演会講 演論文集, 2000 .

[2] Y. Sone. Thermal creep in rarefied gas. J.Phys.Soc.Jpn., Vol. 21, pp. 1836-1837, 1966.

[3] 関伸彦. 分子動力学法を用いた固体表面近傍における非平衡流 動構造の解明, 1999. 東京大学修士論文.

[4] 小竹進. 熱流体の分子動力学. 丸善, 1998.

Link 1: case1 における分子運動 (QuickTime 形式) Link 2: case3 における分子運動 (QuickTime 形式) 